THE MOST BEAUTIFUL GIRL IN THE WORLD 



\section{THE MOST BEAUTIFUL GIRL IN THE WORLD}

BEAUTY PAGEANTS AND NATIONAL IDENTITY

SARAH BANET-WEISER

UNIVERSITY OF CALIFORNIA PRESS

BERKELEY LOS ANGELES LONDON 
University of California Press

Berkeley and Los Angeles, California

University of California Press, Ltd.

London, England

(C) 1999 Sarah Banet-Weiser

Library of Congress Cataloging-in-Publication Data

Banet-Weiser, Sarah

The most beautiful girl in the world : beauty pageants and national identity / Sarah Banet-Weiser.

p. $\mathrm{cm}$.

Includes bibliographical references.

ISBN 0-520-21789-6 (alk. paper).-ISBN o-520-21791-8 (pbk. :

alk. paper)

1. Miss America Pageant, Atlantic City, N.J. 2. Beauty contestsUnited States. 3. National characteristics. 4. Racism in popular culture. 5. Miss Universe Pageant. I. Title.

HQ1220.U5B36 1999

$791.6^{\prime} 2-\mathrm{dc} 21$

99-19922

CIP

Manufactured in the United States of America

$\begin{array}{llllllllllllllllllll}08 & 97 & 06 & 05 & 04 & 03 & 02 & 01 & 00 & 99 & 10 & 9 & 8 & 7 & 6 & 5 & 4 & 3 & 2 & 1\end{array}$

The paper used in this publication meets the minimum requirements of ANSI/NISO Z39.48-1992 (R 1997) (Permanence of Paper). $\infty$ 
for

Bill, Sam, and Luke 
